\title{
Inhibition of dehydrogenase activity in bacterial isolates from palm wine by extracts of Vernonia amygdalina
}

\author{
H.O. NJOKU ${ }^{1 *}$, C.O. AKUJOBI ${ }^{2}$ and J.N. OGBULIE ${ }^{2}$ \\ ${ }^{I}$ Department of Microbiology, Faculty of Science, University of Port-Harcourt, Port-Harcourt, \\ Rivers State, Nigeria. \\ ${ }^{2}$ Department of Microbiology, School of Science, Federal University of Technology, PMB 1526, Owerri, \\ Imo State, Nigeria. \\ *Corresponding author, E-mail: henrynjoku@yahoo.com; Tel: +2348033103314.
}

\begin{abstract}
Inhibition of dehydrogenase activity of bacterial isolates from palm wine by leaf extracts of Vernonia amygdalina was investigated. The cultures were exposed to extract concentrations of $0-2500 \mu \mathrm{g} / \mathrm{ml}$ in a nutrient broth-glucose-TTC medium. The responses of the bacterial strains varied with extract concentration. In all the isolates, dehydrogenase activities were progressively inhibited with increasing concentration of extract. The $\mathrm{IC}_{50}$ ranges from $83.27 \pm 4.9$ to $736.82 \pm 13.6 \mu \mathrm{g} / \mathrm{ml}$. Total inhibitory concentrations for E. coli, Lactobacillus and Streptococcus species were $1984.93 \pm 16.5,2102.82 \pm 22.8$ and $2476.79 \pm 27.7 \mu \mathrm{g} / \mathrm{ml}$ respectively. The total inhibitory concentrations of the remaining isolates (Staphylococcus, Micrococcus and Bacillus species) were beyond the extract concentrations used. The findings may be of clinical relevance and further substantiates the traditional use of extracts of Vernonia amygdalina to control microbial load and foaming in palm wine.

(C) 2010 International Formulae Group. All rights reserved.
\end{abstract}

Keywords: Vernonia amygdalina, dehydrogenase activity, palm wine, Elaeis guineensis Raphia hookeri, Raphia vinetera.

\section{INTRODUCTION}

Vernonia amygdalina belong to the family Compositae and was named after William Vernon, a $17^{\text {th }}$ century botanist (Keay, 1989). It is abundant in grassland throughout the tropics and warmer regions. It is well known as a source of chew stick and for its bitter taste. It is a popular leafy vegetable among the Ibos of Eastern Nigeria. Its antibacterial properties have been evaluated by Akujobi et al. (2006) and it has been shown to contain cardiac glycosides, saponins, tannins and alkaloids (Akujobi et al., 2006). Extracts of the leaves of Vernonia amygdalina are used among the traditional palm wine tapers in Eastern Nigeria to control the microbial load and foaming in palm wine.

Palm wine is an alcoholic beverage produced from a variety of palms such as oil palm (Elaeis guineensis) and raphia palm (Raphia hookeri and R. vinetera). It is drunk in the tropical and subtropical Africa (Okafor, 1978). The sap, irrespective of its origin, is usually a whitish liquid, which effervesces carbon dioxide during fermentation by microorganisms. Palm wine contains 
appropriate nutrients, which can support the growth of pathogenic organisms. Among these nutrients are cis-aconic acid, thiamine, riboflavin, pyridoxine and ascorbic acid, as well as protein and simple sugars (Oyagade et al., 2004). Some microorganisms shown to be associated with palm wine are Leuconostoc mesenteroides, Staphylococcus aureus, Klebsiella pneumonia, Escherichia coli, Lactobacillus plantarum, Lactobacillus lactis, Lactobacillus acidophilus, Leuconostoc lactis, Saccharomyces torulopsis, Saccharomyces cerevisiae and Saccharomyces chevalieri. (Oyagade et al., 2004).

Measurement of microbial enzyme activity has been used in the assessment of ecotoxicological impacts of environmental substrates. In this regard, dehydrogenase activity has been widely used. The dehydrogenase assay is an effective primary test for assessing the potential toxicity of metals to soil microbial activities (Aoyama and Nagumo, 1997; Chander and Brookes, 1995; Kelly and Tate, 1989; Rogers and Li, 1985), toxicity of metals to planktonic (Nweke et al., 2006) and heterotrophic (Nweke et al., 2007) bacteria from tropical river sediments. Toxicity of plant extracts to pathogenic bacteria has been assessed using the dehydrogenase assay (Nwaogu et al., 2007; Nwaogu et al., 2008; Alisi et al., 2008)

The aim of the study is to examine the inhibitory activity of dehydrogenase of bacteria isolates in palm wine as a means of control of microbial load in palm wine. This study will also expose new frontiers or improve on the current application of the plant extracts.

\section{MATERIALS AND METHODS}

\section{Sample collection and preparation}

The leaves of Vernonia amygdalina were collected from Nekede, Owerri-west LGA of Imo State, Nigeria. Dr F.N. Nbagwu, a plant taxonomist of the Department of Plant Science and Biotechnology, Imo State
University, Owerri, Nigeria, identified the plant.

The fresh leaves were dried for four days. The dried leaves were ground into powder form using mechanical grinder. To $100 \mathrm{~g}$ of the leave powder in a conical flask were added $200 \mathrm{ml}$ of $95 \%$ ethanol. This was covered, shaken every $30 \mathrm{~min}$ for $6 \mathrm{~h}$ and then allowed to stand for five days. The solution was subsequently shaken and filtered using Whatmann number 1 filter paper. The filtrate was evaporated to dryness using a rotary evaporator (Model type 349/2, Corning ltd). The extract was stored at $4{ }^{\circ} \mathrm{C}$.

Fresh raphia palm wine were collected from palm wine tapers in Imo State using sterile containers and transported on ice to the laboratory. They were analyzed within $1 \mathrm{~h}$ of collection. Bacterial isolates were obtained from the palm wine using pour plate method after 10-fold serial dilution of the palm wine sample. The isolates were identified using their morphological and biochemical characteristics (Ogbulie et al., 2007). The bacterial isolates were Lactobacillus sp., Micrococcus sp., Streptococcus sp., Bacillus sp., Staphylococcus sp. and Esherichia coli.

The bacterial isolates were grown to mid exponential phase in nutrient broth (Lab M) on a rotary incubator $(150 \mathrm{rpm})$ at room temperature $\left(28 \pm 2{ }^{\circ} \mathrm{C}\right)$. The cells were harvested by centrifugation at $6000 \mathrm{rpm}$ for 8 min and washed thrice in distilled water. The washed cells were re-suspended in distilled water and the turbidity adjusted to an optical density of 0.85 at $500 \mathrm{~nm}$. An aliquot of 0.3 $\mathrm{ml}$ of the cell suspension was used as inoculum in the dehydrogenase activity assay. The dry weight of the cells was determined by drying a $10 \mathrm{ml}$ aliquot of cell suspension in a pre-weighed crucible to constant weight in an oven at $110{ }^{\circ} \mathrm{C}$.

\section{Antimicrobial activity evaluation}

The dehydrogenase assay method as described by Alisi et al. (2008) and Nweke et al. (2007) was adopted for this study. The 
dehydrogenase activity (DHA) was determined using 2,3,5-triphenyltetrazolium chloride (TTC) as the artificial electron acceptor, which was reduced to the redcoloured triphenylformazan (TPF). The assay was done in $4 \mathrm{ml}$ volumes of nutrient brothglucose-TTC medium supplemented with varying concentrations $(0-2500 \mu \mathrm{g} / \mathrm{ml})$ of the leaf extract in separate screw-capped test tubes. About $0.3 \mathrm{ml}$ volume of the bacterial suspension was inoculated into triplicate glass tubes containing $2.5 \mathrm{ml}$ of phosphate-buffered ( $\mathrm{pH}$ 6.8) nutrient broth-glucose medium supplemented with varying concentrations of the plant extract solution. They were incubated in a rotary incubator $(150 \mathrm{rpm})$ at room temperature $\left(28 \pm 2{ }^{\circ} \mathrm{C}\right)$ for $30 \mathrm{~min}$. Thereafter, $1 \mathrm{ml}$ of $0.4 \%(\mathrm{w} / \mathrm{v})$ TTC in deionized water was added to each tube to obtain final extract concentrations of 0,20 , 50, 100, 200, 400, 800, 1400, 2000 and 2500 $\mu \mathrm{g} / \mathrm{ml}$ in different test tubes. The control consisted of the isolates and the medium without Vernonia amygdalina extract. The reaction mixture was further incubated statically at room temperature $\left(28 \pm 2{ }^{\circ} \mathrm{C}\right)$ for $16 \mathrm{~h}$. The triphenylformazan produced was extracted in $4 \mathrm{ml}$ amyl alcohol and determined spectrophotometrically at $500 \mathrm{~nm}$. The amount of formazan produced was determined from a dose-response curve $[0-200 \mu \mathrm{g} / \mathrm{ml} \mathrm{TPF}$ (Sigma) in amyl alcohol]. Dehydrogenase activity was expressed as mg of TPF formed per mg dry weight of cell biomass per hour. Inhibition of dehydrogenase activity in the isolates by Vernonia amygdalina extract was calculated relative to the control. The percentages of inhibition of each of the test organisms were linearized against the concentrations of the extracts using gamma parameter ( $\mathrm{r}$ ) $[\mathrm{r}=\%$ Inhibition / (100 - \% inhibition)] (Kim et al., 1994). The toxicity threshold concentrations $\left(\mathrm{IC}_{50}\right)$ were then determined from the linear regression plots. The total inhibitory concentrations $\left(\mathrm{IC}_{100}\right)$ were estimated from the linear regression of $\log$ transformation plots of the dose-response data.

\section{Statistical analysis}

Data obtained from this study were analyzed using two-way analysis of variance (ANOVA) and values for $\mathrm{P}<0.05$ were considered statistically significant.

\section{RESULTS AND DISCUSSION}

Six different pathogenic bacterial species were isolated from palm wine. They are E. coli, Staphylococcus sp., Bacillus sp., Lactobacillus sp., Streptococcus sp. and Micrococcus sp. Some of these bacterial species (E. coli, Lactobacillus and Staphylococcus) were reported by Oyagade et al. (2004) to be associated with palm wine. However, Streptococcus, Bacillus and Micrococcus species may be contaminants from the vessels used for the palm wine. This also proves that palm wine has enough nutrients to support the growth of pathogenic microorganisms (Oyagade et al., 2004).

The six organisms, when subjected to dehydrogenase assay, showed that they were able to reduce TTC to the red formazan at variable rates. The dehydrogenase activities of the isolates showed that $E$. coli with $1.127 \pm$ $0.032 \mathrm{mg}$ of formazan formed per mg cell dry weight per hour had the least dehydrogenase activity, followed by Lactobacillus $(1.255 \pm$ $0.042 \mathrm{mg}$ formazan $/ \mathrm{mg}$ cell dry weight $/ \mathrm{h}$ ). The highest dehydrogenase activity was obtained with Bacillus sp. $(2.316 \pm 0.51 \mathrm{mg}$ formazan/mg cell dry weight/h) (Table 1). This is at variance with the work of Nweke et al. (2006) in which the gram-negative bacteria had higher rate of dehydrogenase activity than the gram-positive ones. These variations may be due to differences in bacterial physiology, including cell wall components or dehydrogenase systems, since different microorganisms have been reported to have different dehydrogenase systems (PraveenKumar, 2003) However, the present study is in consonance with reports of earlier studies 
(Nweke et al., 2007; Nwaogu et al., 2007; Nwaogu et al., 2008; Alisi et al., 2008).

The effect of the different concentrations of the extracts on the bacterial isolates with respect to the dehydrogenase activity is shown in Figure 1. The response of the bacterial dehydrogenase activities to the extracts is concentration-dependent and varies among the organisms. Dehydrogenase activities were inhibited progressively with increase in concentrations of the extracts in all the bacterial species. However, E. coli was most sensitive to the deleterious effect of the extracts followed by Lactobacillus, while Staphylococcus was more tolerant than the other isolates as depicted by the threshold inhibitory concentration of the extracts against the test organisms (Table 2). The dehydrogenase activity correlated with extracts concentrations with $\mathrm{R}^{2}$ values greater than $0.88\left(0.8833 \leq \mathrm{R}^{2} \leq 0.9801\right)$ in all the bacterial isolates (Figure 2).

Table 1: Dehydrogenase activities in the control tests.

\begin{tabular}{lc}
\hline Test Organism & $\begin{array}{c}\text { Dehydrogenase Activity } \\
\text { (mg formazan/mg cell dry weight/h) }\end{array}$ \\
\hline E. coli & $1.127 \pm 0.032$ \\
Micrococcus $\mathrm{sp}$ & $1.734 \pm 0.026$ \\
Staphylococcus $\mathrm{sp}$ & $2.132 \pm 0.12$ \\
Streptococcus $\mathrm{sp}$ & $1.624 \pm 0.053$ \\
Bacillus $\mathrm{sp}$ & $2.316 \pm 0.51$ \\
Lactobacillus $\mathrm{sp}$ & $1.255 \pm 0.042$ \\
\hline
\end{tabular}

TABLE 2: Threshold inhibitory concentrations of V.amygdalina extract against the bacterial isolates.

\begin{tabular}{lcc}
\hline \multirow{2}{*}{ Test organisms } & \multicolumn{2}{c}{ Inhibitory Concentrations $(\boldsymbol{\mu g} / \mathbf{m l})$} \\
\cline { 2 - 3 } & IC $_{\mathbf{5 0}}$ & IC $_{\mathbf{1 0 0}}$ \\
\hline & & \\
Streptococcus $\mathrm{sp}$ & $324.38 \pm 7.2$ & $2476.79 \pm 27.7$ \\
E. coli & $83.27 \pm 4.9$ & $1984.93 \pm 16.5$ \\
Micrococcus $\mathrm{sp}$ & $423.00 \pm 10.1$ & $\mathrm{ND}$ \\
Bacillus $\mathrm{sp}$ & $736.82 \pm 13.6$ & $\mathrm{ND}$ \\
Lactobacillus $\mathrm{sp}$ & $214.93 \pm 6.3$ & $2102.82 \pm 22.8$ \\
Staphylococcus $\mathrm{sp}$ & $431.41 \pm 9.7$ & $\mathrm{ND}$ \\
& & \\
\hline $\mathrm{ND}=$ Not determined $($ above $2500 \mu \mathrm{g} / \mathrm{ml})$ & &
\end{tabular}

$\mathrm{ND}=$ Not determined (above $2500 \mu \mathrm{g} / \mathrm{ml})$ 

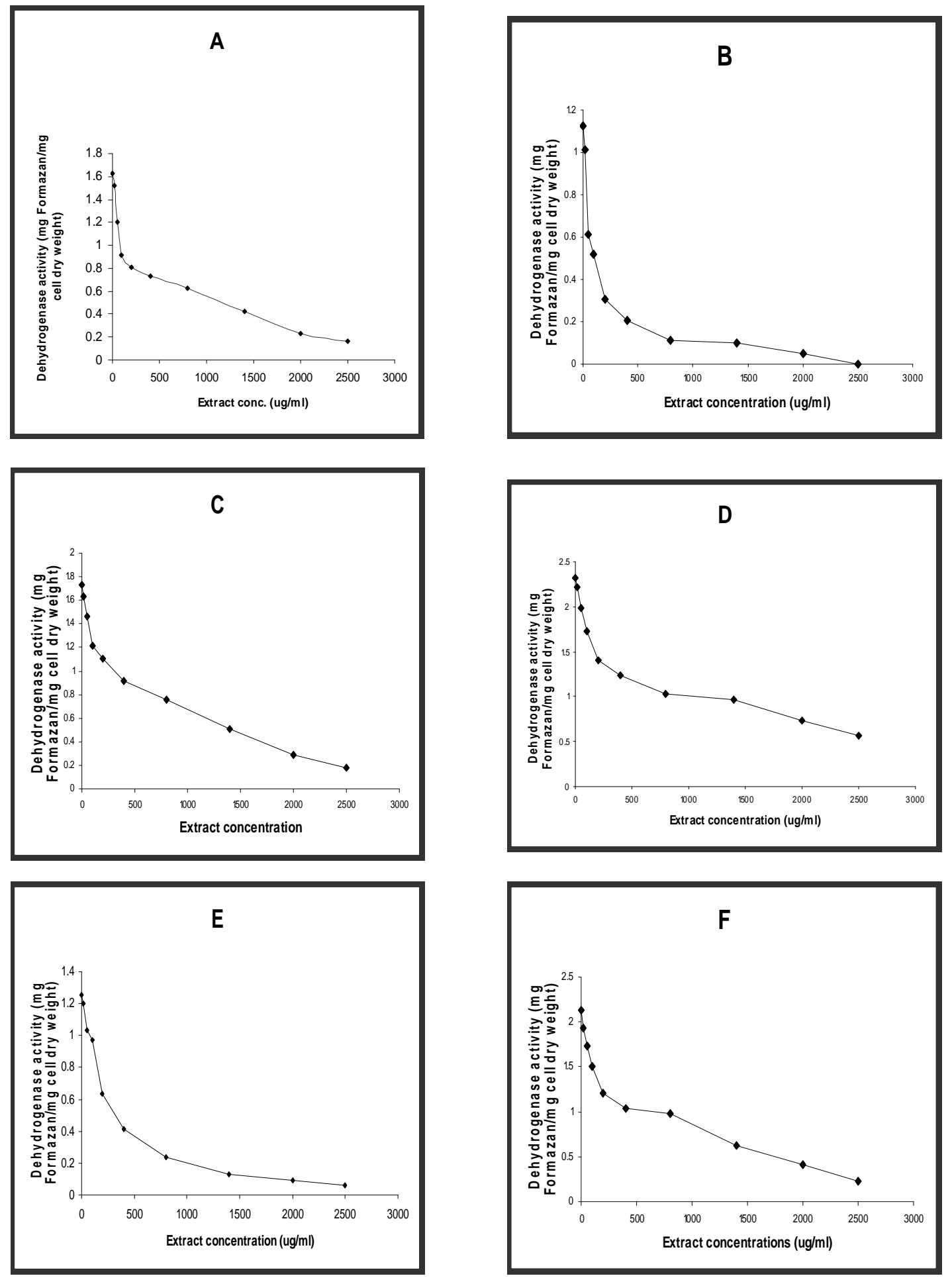

Figure 1: Dehydrogenase activity of (A) Streptococcus sp., (B) E. coli, (C) Micrococcus sp., (D) Bacillus sp., (E) Lactobacillus sp., (F) Staphylococcus sp. in response to various concentrations of Vernonia amygdalina. 

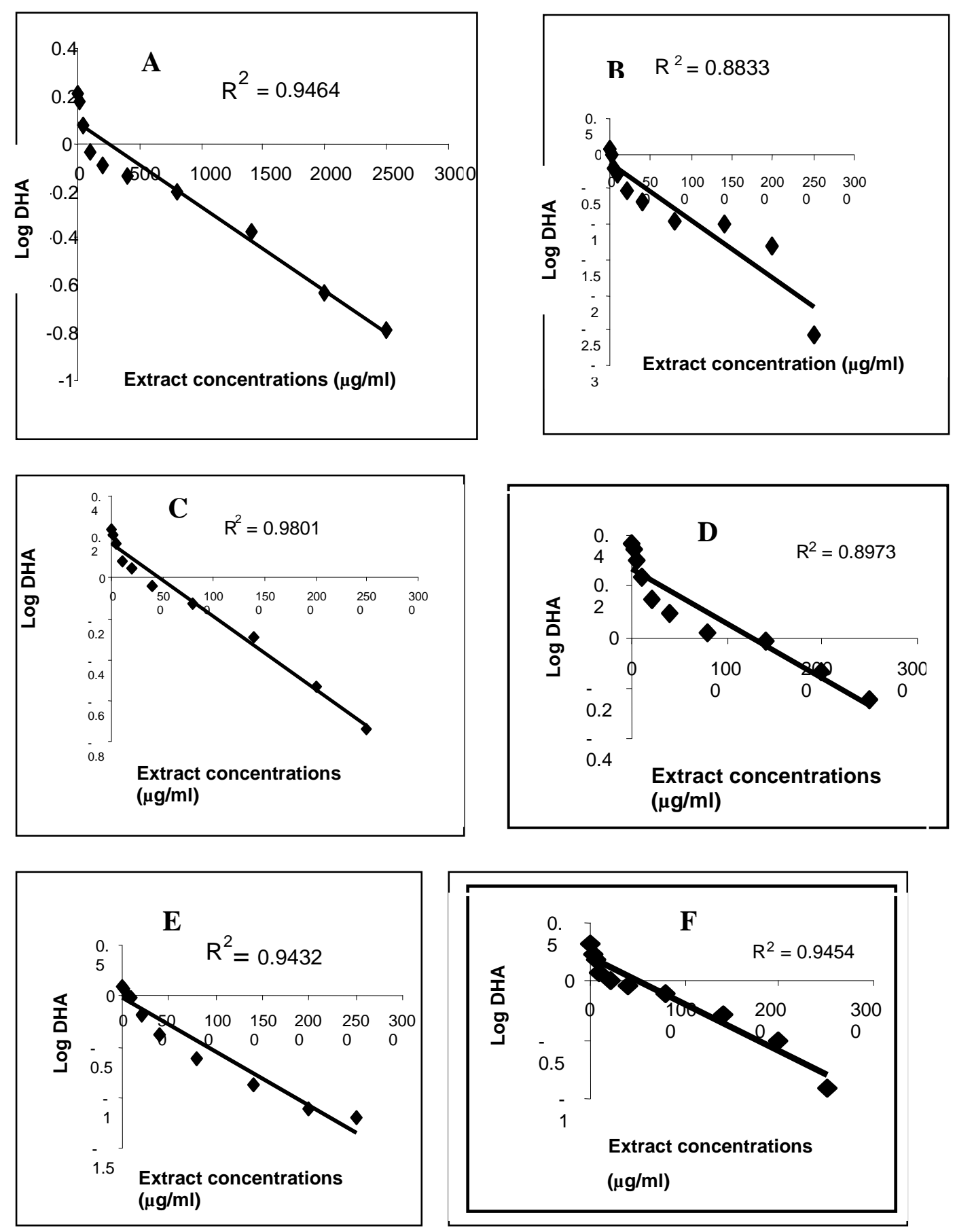

Figure 2: The log transformed plot of dehydrogenase activity of (A) Streptococcus sp., (B) E. coli, (C) Micrococcus sp., (D) Bacillus sp., (E) Lactobacillus sp., (F) Staphylococcus sp. in response to various concentrations of Vernonia amygdalina. 

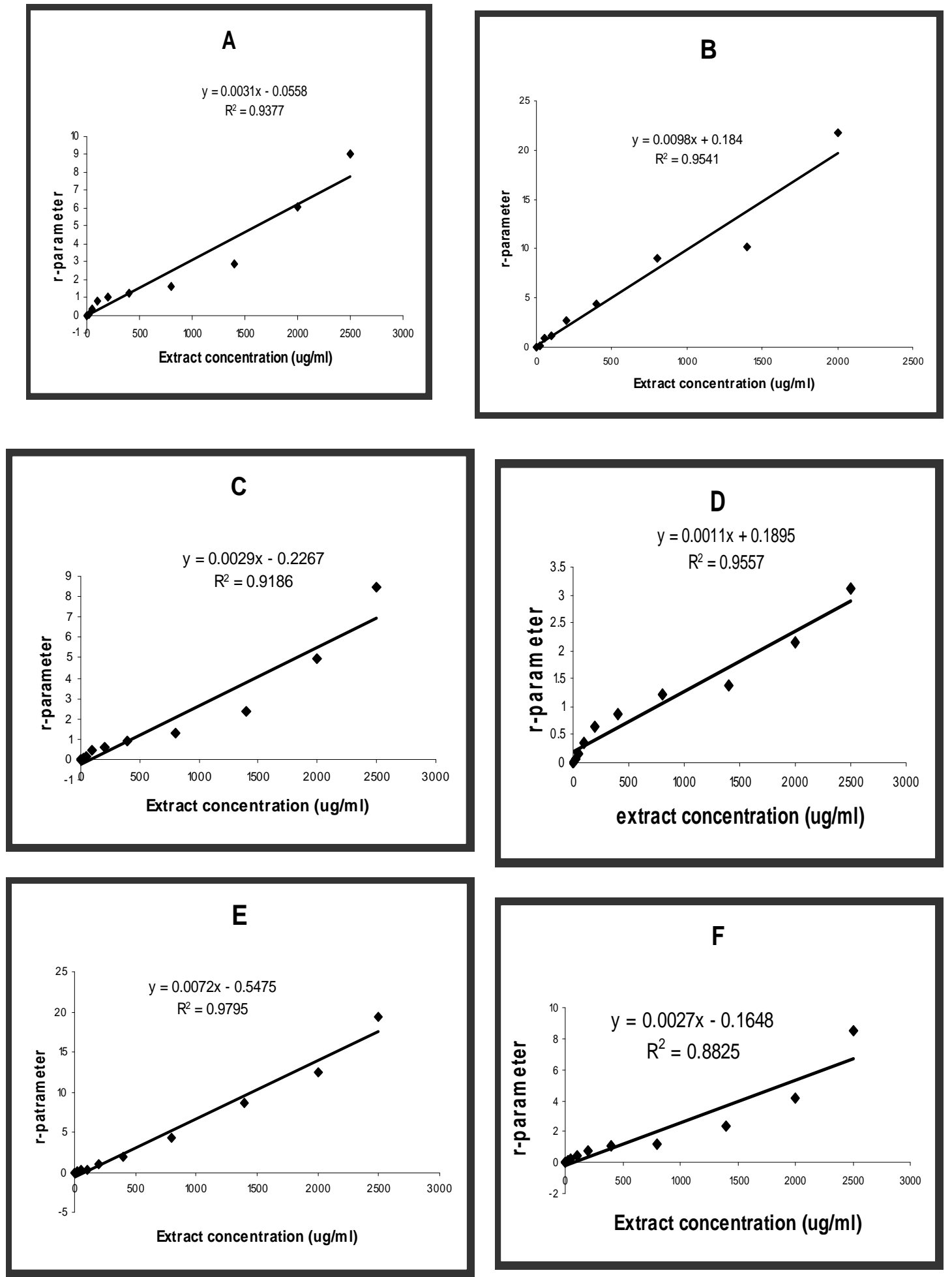

Figure 3: Gamma (Г) parameter values of (A) Streptococcus sp., (B) E. coli, (C) Micrococcus sp., (D) Bacillus sp., (E) Lactobacillus sp., (F) Staphylococcus sp. in response to various concentrations of Vernonia amygdalina. 
The high $\mathrm{R}^{2}$ values (>0.88) observed with all the bacterial isolates indicated that extract concentration was a strong determinant of the dehydrogenase activity. This indicated that increase in the concentration of the extract would seriously affect the carbon metabolism and respiratory activities in these bacterial isolates. This finding corroborates the reports of Osadebe and Ukwueze (2004) who found that various plant extracts inhibit the growth of some hospital bacterial isolates.

The gamma parameter gave a good linearization of the dose-response data with the $\mathrm{R}^{2}$ values greater than $0.88\left(0.8825 \leq \mathrm{R}^{2} \leq\right.$ $0.9795)$ in all the bacterial isolates. The gamma parameter models had higher $\mathrm{R}^{2}$ values than the $\%$ inhibition plots (results not shown) and hence the linear regression models were used to assess the threshold inhibitory concentration of the extracts on the organisms. The 2-way analysis of variance shows that the dehydrogenase activity varied significantly $(\mathrm{P}<0.05)$ with bacterial strain and extract concentration.

In conclusion, the extract of Vernonia amygdalina inhibited the dehydrogenase activity of E. coli, Staphylococcus sp., Bacillus sp., Streptococcus sp., Lactobacillus sp. and Micrococcus sp. The inhibitory action may be due to the presence of cardiac glycosides, saponnins, tannins and/or alkaloids reported in our earlier study (Akujobi et al., 2006). This study further justifies the use of leaf extracts of Vernonia amygdalina in the control of microbial load and foaming in palm wine among the traditional palm wine tapers in Eastern Nigeria.

\section{REFERENCES}

Akujobi CO, Ogbulie JN, Uchegbu UN. 2006. Antibacterial activities and preliminary phytochemical screening of Vernonia amygdalina and Citrus aurantifolia. Nig. J. Microbiol., 20(1): 649-654.

Alisi CS, Nwanyanwu CE, Akujobi CO, Ibegbulem CO. 2008. Inhibition of dehydrogenase activity in pathogenic bacteria isolates by aqueous extracts of
Musa paradisiaca (var sapientum). Afri. J. Biotechnol., 7(12): 1821-1825.

Aoyama M, Nagumo T. 1997. Effects of heavy metal accumulation in apple orchard soils on microbial biomass and activities. Soil Sci. Plant Nutri., 43: 821831.

Chander K, Brookes PC. 1995. Microbial biomass dynamics following Addition of metal-enriched sewage sludge to a sandy loam. Soil Biol. Biochem., 27: 1409-1421.

Keay RWJ. 1989. Trees of Nigeria. Clarendon Press: Oxford.

Kelly JJ, Tate RL. 1989. Effects of heavy metal contamination and remediation on soil microbial communities in the vicinity of a zinc smelter. J Environ. Qual., 27: 609-617.

Kim CW, Koopman B, Bitton G. 1994. INTDehydrogenase activity test for assessing chloride and hydrogen peroxide inhibition of filamentous pure cultures and activated sludge. Water Res., 28: 1117-1121.

Nwaogu LA, Alisi SC, Ibegbulem CO, Igwe CU. 2007. Phytochemical and antimicrobial activity of ethanolic extract of Landolphia owariensis leaf. Afri. J. Biotechnol., 6(7): 890-893.

Nwaogu LA, Alisi SC, Igwe CU, Ujowundu CO. 2008. A Comparative study of the antimicrobial properties of the ethanolic extracts of Landolphia owariensis leaf and root. Afri. J. Biotechnol., 7(4): 368372.

Nweke CO, Okolo JC, Nwanyanwu CE, Alisi CS. 2006. Response to planktonic bacteria of new Calabar River to zinc stress. Afri. J. Biotechnol., 5(8): 653-658.

Nweke CO, Alisi CS, Okolo JC, Nwanyanwu CE. 2007. Toxicity of zinc to heterotrophic bacteria from a tropical river sediment. Appl. Ecol. Environ. Research., 5(1): 123-132.

Ogbulie TE, Ogbulie JN, Njoku HO. 2007. Comparative study on the microbiology and shelf life stability of palm wine from Elaeis guineensis and Raphia hookeri obtained from Okigwe, Nigeria. Afri. J. Biotechnol., 6(7): 914-922. 
Okafor N. 1978. Microbiology and biochemistry of oil palm wine. Advan. Appl. Microbiol., 24: 237-256.

Osadebe PO, Ukwueze SE. 2004. A comparative study of the phytochemical and antimicrobial properties of the Eastern Nigerian species of African mistletoe (Loranthus micronthus) sourced from different host trees. J. Biol. Biotechnol., 2(1): 18-23.

Oyagade AO, Famurewa O, Oyagade JO, Aringbangba JO. 2004. Microbial population and survival of some pathogenic bacteria in fresh palm wine. Nig. J. microbiol., 18(1-2): 269-276.

Praveen-Kumar JC. 2003. 2,3,5Triphenyltetrazolium chloride (TTC) and electron acceptor of culturable cell bacteria, fungi and actinomycetes. Biol. Fert. Soil., 28: 186-189.

Rogers EJ. Li SW. 1985. Effects of metal and other inorganic ions on soil microbial activity: soil dehydrogenase assay as a simple toxicity test. Bull Environ. Contam. Toxicol., 34: 858-865. 